\title{
REPRESENTATION OF KOREAN TEENAGERS IN INDONESIAN LITERARY WORKS
}

\author{
Dwi Widyaningrum YULIAWATI \\ Universitas Gadjah Mada, Faculty of Cultural Sciences \\ Yogyakarta, Indonesia \\ yuliawati.ng@ugm.ac.id \\ nining.ydw@gmail.com
}

\begin{abstract}
It can be said that Korean Wave has triggered the appearance of a new chapter in Indonesian literature works, namely the emergence of literature works related to Korea. Indonesian writes all of these fictions and majority featuring Korean, especially Korean teenagers as the character and use Korea related problems as story theme, setting, etc. This paper is discussing how Korean teenagers represented in Indonesian teenage literature works. Representation is meant here is as the depiction or reflection that symbolizes social reality. Of course, reality reflected in a literary work is not always an actual fact, there is frequent a tendency of reality idealized by the author, in this case is Indonesian author's idealism. From the examination undertaken on Summer in Seoul and Oppa and I: Love Signs teenage fictions showed the following results. Seen from the perspective of adolescence developmental psychology, Korean teenagers are constructed as figure who have had mature personality, who have achieved emotional, moral, social, and intellectual independence. As a member of a family, Korean adolescent represented as a son, daughter, brother, and sister who do not only take responsibility for themselves but also for others. Then from the perspective of their relation with peers group, they are described as teenagers who have been able to expand their social relationships and have also been able to maintain those relationships. Furthermore, within in the context
\end{abstract}


of education, Korean teenagers are described as young people who have been able to draw up a clear plan for the future.

Key words: teenage literature, Korean teenager, representation, adolescence developmental psychology

\section{WIZERUNEK KOREAŃSKIEGO NASTOLATKA W LITERATURZE INDONEZYJSKIEJ}

Streszczenie: 'Koreańska Fala' (Hallyu) doprowadziła do powstania nowego rozdziału w literaturze indonezyjskiej, a mianowicie utworów literackich traktujących o Korei. Autorzy pochodzenia indonezyjskiego chętnie wykorzystują w swojej fikcji literackiej postacie koreańskich nastolatków czy wątki dotyczące Korei.

Celem niniejszego artykułu jest omówienie wizerunku koreańskiego nastolatka zawartego w indonezyjskiej literaturze młodzieżowej, w kontekście realiów społecznych. Realia, o których tu mowa nie zawsze są jednak prawdziwe, co wynika $\mathrm{z}$ faktu ich idealizowania przez wspomnianych twórców. Analiza 'Summer in Seoul' oraz 'Oppa and I: Love Signs' ukazuje koreańskich nastolatków jako ludzi o dojrzałej osobowości, którzy osiągnęli niezależność emocjonalną, moralną, społeczną i intelektualną. Jako członkowie rodziny - syn, córka, brat czy siostra to osoby biorące odpowiedzialność nie tylko za siebie, ale także i za innych. W kontekście relacji z grupą rówieśniczą, potrafią nawiązywać oraz podtrzymywać znajomości, a w kontekście edukacji ukazywani są jako młodzi ludzie, potrafiący kreślić swoje plany na przyszłość.

Słowa klucze: literatura młodzieżowa, koreański nastolatek, wizerunek, psychologia rozwojowa nastolatków

\section{인도네시아 문학 작품에 나타난 한국 청소년}

개략: 이 연구는 인도네시아 청소년 문학 작품에서 한국 청소년이 어떻게 묘사되는지 논의하고 있다. 청소년 발달 심리학의 관점에서 보면 <Summer in Seoul (서울 여름)>과 <Oppa \& I: Love Signs (오빠와 나: 사랑의 신호)>라는 인도네시아 청소년 소설에서 나타난 한국 청소년들이 정서적, 도덕적, 사회적 및 지적 독립성을 달성한 성숙한 성격을 지닌 인물로 구성된다. 가족 구성원으로서 한국 청소년들은 자신뿐만 아니라 다른 사람들에 대해서도 책임을 지는 자녀와 형제로 나타난다. 그리고 또래집단과의 관계 관점에서 그들은 사회적 관계를 확장도 할 수 있었고 유지도 할 수 있었던 청소년으로 묘사된다. 또한 교육의 맥락에서 미래에 대한 명확한 계획을 세울 수 있는 젊은 사람들로 표현된다. 
키워드: 인도네시아 청소년 문학, 한국 청소년, 묘사, 청소년 발달 심리학

\section{Introduction}

It can be said that the influx of Korean popular culture in Indonesia was began with the airing of 'Winter Sonata' and 'Endless Love' in 2002 in Indosiar Television. The success obtained by these two dramas followed by the broadcasting of other Korean dramas. And the increasing of Indonesian public interest in Korean drama made other television channels airing Korean drama too. The strength of Korean drama treats the saturation of Indonesian to local drama. Since then, Korean drama flooding in Indonesia could not be dammed up. The popularity of Korean dramas also caused some production house in Indonesia adapted the story of Korean drama in their productions. 'My Girl' (2006) and '9 End 2 Outs' (2009) is an example of Korean drama had been remade in Indonesian version.

Meanwhile, through those dramas Indonesian got to know Korean music or K-Pop. Many of drama's soundtracks became hit and loved by Indonesian young generation. Not long after that, the popularity of soundtrack sang by a Korean soloist in Indonesia followed by the entry of Korean boy bands and girl bands. The presence of Korean boy bands and girl bands, such as Super Junior, SHINee, Big Bang, SNSD, T-ara, Wondergirls, etc. are welcome enthusiastically by Indonesian young generation. The appearance of these groups was interesting phenomenon for Indonesian. Their music and dance, explosive energy, and powerful presentation of the Korean artists could hypnotize the youth of Indonesian who need another alternative of music entertainment. Since they had stolen the hearts of music lovers in Indonesia successfully, the 'invasion' of K-Pop in Indonesian music industry could not be stopped anymore. This phenomenon opened a new business area in music industry in Indonesia. K-Pop music has its own market in Indonesia. This new genre of popular culture has been seen as an opportunity to get a big profit. Behind this condition, some music producers decided to create Indonesian boy band and girl 
band oriented on K-Pop genre. It can be said that 2012 is the peak of Indonesian boy band and girl band existence. There were a lot of group bands created. SM * SH (SMASH), MAX5, Dragon Boyz, Mr. Bee, NSG Star, S9B, Hitz, XO-IX, 3 In One were example of Indonesian boy bands, while Cherry Belle, 7 Icons, G String, 5 Angel, Minni, Super Girlies, Mascara, and Tina and D'Girls were some examples of Indonesian girl bands who referred to the K-Pop. In between pro and anti, there is no denying that the existence of Indonesia's boy bands and girl bands enliven the music life in Indonesia. Even though many critics referred to them that they only imitate Korean bands, it is a fact that some of Indonesian accept, acknowledge, and enjoy their existence.

In Indonesia, Korean fever did not only penetrate in local drama and music but also affected in many aspects of Indonesian community life. Some of Indonesian started to study Korean language, culture, consume Korean fashion style, Korean cosmetic, etc. Local media, such television, radio, Internet, and magazines began inserted something about Korean or Korea in their cultural content. Unmitigated, Korean wave also penetrated into Indonesian literary work. As we all know, nowadays, literary and creative industries are something cannot be separated. Viewed from a business perspective, a literary work is no longer only had a role as cultural product, but also as industrial product. In other words, literary works are considered as "commodities" which become one means to seek profit. The process of industrialization led to literary works almost completely engaged in the interests of the market. In its position as a commodity, literary works often have to adjust with the interests of the market, so that consumer tastes often determine the pattern of these commodities. The enormous number of Indonesian teenagers who are curious everything about Korea creates enormous market opportunities for Korean teenage literature. Of course the capitalist, in this case the publisher, does not waste this opportunity. They began to publish special literary works for them, Korean teenager literary translated in Indonesian. Seeing this, local authors also do not want to miss this opportunity. They are also competing to meet the market demand. Finally this phenomenon gave rise to an interesting fact in the development of Indonesian literature. Namely, up to now it is not difficult to find literary works contain about Korea. Korean comic books, books, novels, and teenager literary works or abbreviated teenlits translated in Indonesian and teenlits related 
to Korea written by Indonesian quite easily can be found in a bookstore. Some Indonesian writers do not only write their teenlits with Korean as characters and Korea as a story's background, but in order to strengthen that the contents of the fictions is about Korea, some authors even use Korean pen name and entitled their works in Korean. Concisely, it can be said that capitalism has encouraged the growth of Indonesian teenage literary about Korea.

This paper tried to examine how the Korean, especially Korean teenager represented in Indonesian literature. As we know, representation is a situation that represents a specific condition. In this study, the meaning of representation is a literary work's depiction of a social phenomenon. In this context, literary work is seen as a depiction, which symbolized a reality. While based on the concept of sociology of literature, literary work is a mirror to the age (Swingewood and Laurenson, 1972:13). However, the representation in literature is not a picture or actual reality, but the fact that idealized by the author. In other words, it's more directed to the depiction of society and social situation through the creative process conducted by the author (Davidson, 1986:24).

The object of this study is two teenlits, namely Summer in Seoul (SS) and Oppa \& I: Love Signs (O\&I). Before examining the representation, structurally examination should have been done first. After that, the representation of Korean teenager will be connected to and based on social status or roles carried by the characters and the relationship between the characters that appear in the story. In this study those teenage characters will be viewed from the perspective of adolescence developmental psychology. Santrock said that in adolescent development, contexts and the settings in which development occur plays important roles (2003: 27). Based on this opinion, teenagers or adolescents who appear in these fictions will be analyzed from three aspects, which are important contexts in a teenager life that is family, peers group, and school or education world. In short, this paper tried to explain the social reality in the Korean teenager's life from the Indonesian author's perspective.

\section{Summer in Seoul and Oppa \& I: Love Signs}


Summer in Seoul (SS) is a teenage fiction written by Ilana Tan and published for the first time in 2006 and reprinted due to the high demand. Whereas Oppa \& I: Love Signs (O\&I) is a collaboration writing of two young writers Orizuka and Lia Indra Andriana, published in 2013. Structurally there are some similarities between both fictions as described below.

\subsection{General Review of Summer in Seoul and Oppa \& I: Love Signs}

Almost all of the characters in both literary works are Korean and named in Korean. Another interesting thing is Han Soon-hee, female main character in SS and Park Jae-in in O\&I are daughter born from multicultural marriage between Korean father and Indonesian mother while male main characters are Korean celebrities, Jung Taewoo, a singer in SS and Choi Seung-won, a movie star in O\&I. And then, brother, parents, and friends in senior high school and university are some of supporting characters appeared. As a female main character, Han Soon-hee who has Indonesian name as Sandi is a university student in her third semester. She is physically described as a girl with a slender in figure and curly hair. And Park Jae-in, female main character in O\&I is a $3^{\text {rd }}$ grade senior high school student, 18 years old girls with long hair, cute, slender in figure, and good in drawing. Both of them also depicted having pretty well behaved. Then, as male main character in the SS, Jun Tae-woo is describe as singer with good voice, has the most captivating smile, neat haircut, a little blonde hair, and has big eyes. Not only good in singing, he is also good in playing piano and arranging romantic songs. Fashion he wore always became a trendsetter for young people. Then Choi Seung-won in O\&I is 3th grade senior high school student. Both Tae-woo and Seung-won are describe having high sense of humor, good looking, and tall.

The major theme in both teenlits is teenage love story. Love story between girls born from multicultural marriage with Korean celebrity. And Korean educational world is one of the subthemes. The authors present the story chronologically. In SS, the story began when Han Soon-he's phone get accidentally exchanged with phone of June 
Tae-woo's manager. This incident finally made Han Soon-hee meet and interrelate with Tae-woo. While in O\&I, the story began with the spread of untrue gossip about Park Jae-in and Choi Seung-won. Both of these teen fictions end with a happy ending, the involvement of the two couples in a romantic relationship. The stories in SS take place in Seoul and Jakarta, while O\&I takes place in Seoul and Busan. Based on the story, all the events depict current conditions and the authors to deliver the story use third person perspective. Social background that appears in these two stories is teenage life that includes teenage romance, life around the education world, friendship, and the world of internship.

Seen from the language used, the authors deliver the stories using informal Indonesian, so there is no difficulty for the reader that the majority are Indonesian teenager to follow and understand the story. As if to strengthen the identity that both teenlits are related to Korea, the authors also insert Korean word and even one full Korean sentence in the text. As an example, words such as hyeong, орра, арра, etc. is often used to refer the characters. Then, expression likes jalga, komawoyo, arrasseo, saranghe, and others used by the authors to deliver the expression of the figures.

\subsection{Representation of a Korean Teenager as a Family Member}

In his social life, a teenager has a role as a member of a family that is as a son or daughter for his parents and as a brother or sister for his or her sibling. Characters appear in both fictions are described as a devoted son and daughter for their parents. Always respecting, trying to relieve their parent's burden, and establishing good communication with parents show this attitude of devotion. This construction can be seen especially from the attitudes of Han Soonhee and Park Jae-kwon.

It is said that although living apart from her parents, Han Soon-hee always maintains the trust that her parents gave to her by not letting them worry or feeling embarrassed with her activities. Living alone in Korea makes her should be independent in taking care everything in her daily life by herself, such as managing finances, 
organizing daily activities, taking care of her study, and others. Then, in order not to make her parents worry about her, Han Soon-hee always communicates with them by phone every day.

In O\&I, since his father works in other city, as the oldest son, Park Jae-kwon should take over his father's role frequently. Taking care of his mother and his younger sister and making sure that they are always in a good condition. Instead of his father, he always tries to meet all the things his pregnant mother needs. Jae-kwon also asked his father not to worry about his sister because he's trying to always keep an eye on her sister, either for her study related activities or others.

As a teenager, who is growing up, it can be said that all of the figures in fiction always keep trying to be able to solve problems they are facing by themselves, as problem related to their love story, conflict with a boyfriend or a girlfriend, their studies, place to stay, plan for the future, etc. without depending on other people.

“Appa, let me take care it. I'll keep my eyes on her. If she has a problem, I'll help her... I will ask her again about her plain and help her to think about that. Don't worry, Appa..." (Orizuka \& Indriana, 2013: 90)

"Keep calm, Eomma. I am save and fine. There is nothing to be worried about... I've been thingking about it. I will stay in Youngmi's house for a while and I will be moving as soon as I found new oneroom..." (Tan, 2006)

The attitude of respect to their parents causes them always positioning their parents as someone to consult and ask about various things, ask them for opinion and advice. Besides making their parents as partners in solving a problem, they are also capable of playing a role as a partner for their parents. This is shown by their ability to be a good listener and good advicer when their parents facing a problem or wanting to talk about some problems.

As mentioned before, as a member of a family a teenager also has a relationship with his sibling. In O\&I, as a brother, Park Jaekwon is identified always wants to protect his sister, Park Jae-in. He always wants to make sure that Park Jae-in is always fine. He does not allow anyone hurt her. Therefore, worried his sister might be hurt due her relationship with Seung-won made Jae-kwon opposed to their 
relation at first. His worries is reasonable, because as a celebrity Seung-won must have fans who will not like Jae-in, who will be jealous of her.

Likewise, Park Jae in, as a sister, she always hears and considers his brother's advice and respects him. She really understands why he worried so much about her and so she does not want to make him worried about her condition. She also knows well why he always concerns and sometimes interfered about her life. She can understand that he did it because he has a big responsibility about her.

She conveys her disappointment, disagreements, and protest to her bother gently without any high tones. Through good communication and transparency between them, finally Park Jaekwon is to be believed and sure that his sister would be happy with Seung-won then he changed his attitude from opposed to be support the relationship between Jae-in and Seung-won. For Jae-kwon the happiness of his sister is everything.

Adolescence is a period of searching for self-identity. And according to G. Stanley Hall, father of the scientific study of adolescence, adolescence is the period from 12 to 23 years of age and is filled with storm and stress. Adolescence is a turbulent time charged with conflict and mood swings (Santrock, 2003:7). In other word, in the process of identity searching, teenagers often experience a crash involving them with people around them, like arguing with their parents or their siblings. The divergence between characters with their parents or siblings could not be categorized as quarrel. On the contrary, from the narration and plot found that there is a good communication between them. Nevertheless, the close relationship between members of the family did not cause them to be teenagers that depend on others. On the other hand, freedom that parents give just encourages them to be independent figures, trying not only to solve their own problems by themselves but also to help others solving their problems.

As we know, Korean traditional culture, including relationship pattern in a family is based on the Confucianism, an ethic, which greatly emphasized on filial piety, respecting the elder, and expressing opinion in a very polite manner. A culture based on concept that harmony in a family is as important as the happiness of each family member. Through these fictions, it seems that the authors wanted to give an illustration to the reader that even though Korea has 
changed a lot due to industrialization, family system in Korea still enforces eastern culture which is a culture prioritize good relationship between someone with their parents and also good relationship between siblings. The writers want to describe that industrialization don't make Korean teen left behind their original culture.

Then, according to the adolescence development stages, through the attitudes and behaviors described above, Korean teenagers constructed as figure have reached emotional, moral, social, and intellectual independent which is as a member of a family they have been able to take responsibility not only for themselves but also for the others.

\subsection{Representation of Korean Teenager in Their Relation with Peers Group}

One of the adolescent's characteristics is their bond on a group. Teenagers always want to live in groups, so they will not feel alone in facing a problem. For them groups can be used as a place for sharing, discussing, motivating each other, etc. In line with this, Kimmel said that one of the stages in the adolescence is their involvement in a wider relationship, which is their close relation in a peer group (Kauna, 1999: 9). Peer group relationship formed in SS and O\&I are friendship between senior high school and college's friend. Close relationship tied between main characters and supporting characters which is friendship in senior high school and college proved that as teenagers, characters in these two teenlits have had ability to build a new and a mature relationship than before with their peers both with same and different genders. In SS and O\&I, friends of Han Soon-hee and Park Jae-in are presented as friends, who have high sense of solidarity. Their solidarity is realized by always helped, found solution for the problems main characters are facing, as can be seen below.

"Nowadays, they do not make gossip about you anymore but Tae-jun and Sa-ra!" (...) Tae-jun made a special action and said to Sara that he loved her. He wrote in baseball field with chalk 'I love you, Lee Sa-ra. Without you I'm end' (...) They did it in order 
to obscure scandal about you and Seung-won, Jae-in (...) " (Orizuka \& Andrina, 2013: 45)

After the rumor about her and Seung-won spread widely in school, Jae-in was seen having a hard time in her school with difficult. Knowing that students in her school are talking about her maked Jae-in sad and angry, then she decided not to go to school for two days. As a friend, Tae-jun and Sa-ra have great sympathy and empathy on Jae-in, they can feel what Jae-in felt. Do not want to see they friend being sad, in order to divert rumor, in purposely Tae-jun and Sa-ra made a ridiculous action in their school. Using chalk that their teacher usually used to write in blackboard in class, Tae-jun wrote his feeling to Sa-ra in baseball field, so all of the students and teachers could read it well. Their action proved to be able to divert gossip about Jae-in. Since after that, gossip about them be spread around the entire school replaced rumor about Jae-in and Seung-won. Even, for the shake of Jae-in, Tae-jun and Sara willingly got punishment from the school because using many chalk and school facilities without permission. Their ridiculous action is based on their desire to reduce Jae-in's burden and help her to find out a solution for her problem. In addition, with other friends Tae-jun and Sa-ra always try to console her, always be beside her when she needs friends to talk. Even they voluntarily accompanied her spending summer vacation in Busan and became mediator between her and Seung-won.

Similar with O\&I, in SS, Youngmi, a close friend of Han Soon-he narrated always be beside Soon-he either she is in a good condition or not, like when Soon-hee was sick, her oneroom was on fire, etc. Youngmi also is a friend who will come first when Soonhe needs friend to listen her story, story about her love, her internship, and others. The attitudes and behaviors done by the supporting characters for the main characters indicate a causal connection with what main characters done to her friends.

Santrock and Sarwono said that another characteristic experienced by someone in adolescence is the arising of feeling interested and falling in love with the opposite sex. This phenomenon is also experianced by 4 couples in these two fictions. Sympathy against different gender and desire to meet the need for affection from someone they love become a strong driving for them to finally get in a romantic relationship with someone from opposite sex. Their 
decision about these relations are also followed by their readiness to accept the risk from that relation. For example, have to help her boyfriend finding solution for the problem that boyfriend's family facing as Park Jae-kwon's girlfriend did. And dating secretly to avoid media and fans as Han Soon-he and Park Jae-in did. These kind of attitudes showed that they can commit, tolerance, take a responsibility, and be willing to sacrifice for others.

Through the teen characters who do not think only about themselves, who think that other people or something happend to others is a part of themselves, teenagers who have deep sympaty, empathy, and sense of belonging to others, seems that the authors want to constuct Korean teenagers appeared in SS and O\&I as figure who have had extension of self, an attitute and a condition which showed a mature personality. In other words, close relationship between the characters appeared in both teenlits, the ability of characters solve the conflict faced in their relationship with others indicates that teenagers appeared in these fictions constructed as teenager who have been able to expand their social relation but also have been able to maintain that relationship. They represent teenagers who have reached emotional, moral, and social independent.

\subsection{Representation of Korean Teenager in Education World}

The representation of Korean teenagers related with school or their education world shown through the attitudes and the decisions about education made by teen figures appeared in the SS and O\&I. But let's take a look at today's Korean education life first. Lee Sun-yi said that Korea is one of countries with a very strict competition in the field of education. Attendances at the most prestigious elite as SKY schools (Seoul National University, Korea University, and Yonsei University) confer large advantages on graduates once they hit the labor market. Since graduating from certain university will affect someone's life, will guarantee both social and economic life in the future, so everyone desperately competes to get into the best university. And because of public education is considered not enough to prepare student in that competition, then the parents give their 
children a private education by sending them to a private institution or give them an extra-class. Many Korean students are miserable, especially student in senior high school, as they have to prepare for the highly competitive 'suneung' or College Scholastic Ability Test which determines entry into college. With these conditions it's reasonable if a lot of Korean teenagers feel unhappy as they are under high pressure to perform well at school, their parents pushing them to join those elite higher educational institutes to access the upper echelons of society burden them. They feel extremely exhausted at the end of each day, have little time or energy to share even small talk with her family and friends, and come back home after 11 P.M, have no time for enjoy their life ${ }^{1}$. For these reasons, the happiness index for Korean teenagers was the lowest among the 23 OECD member states $^{2}$. These kind of social circumstances are also described in both teenlits as bellow.

“...Some students read a book while walking into the school... College Scholastic Ability Test (suneung) is only few months left. Same with other senior high school's student, majority of Gangnam Sangdan Senior High School's students determined to go to top ten universities, so what they do is just study and study, day and night. After completing their public education, they still have to go to the private academy and all just finished it at 11 P.M. (...)" (Orizuka \& Andriana 2013:11).

“...Suneung makes all the student has menbung (mental breakdown)... "I study hard until my head smoked"... They only give me 3 days for summer vacation. After that I will enter the hell again" (...)" (Orizuka \& Andriana 2013:96).

In O\&I, it is narrated that Park Jae-in, Park Jae-kwon, and friends have to study hard every day. It's been said that day-by-

\footnotetext{
${ }^{1}$ http://www.koreaherald.com/view.php?ud=20110504000759, http://www.bbc.com/news/education-25187993

${ }^{2}$ Korean children and adolescents' self-reported sense of happiness had recorded between 60 and 70 points from 2009 to 2014, but jumped to 90.4 points in 2015 (19th place among 23 countries) and once again falling to last place in 2016 with 82 points, the lowest level among the OECD member countries.

http://koreabizwire.com/korean-children-and-adolescents-rank-last-in-oecdhappiness-index/53907
} 
day they are busy preparing university entrance exams. Their daily schedule is going to school in the early morning and then going to private academy after that and coming home at 11 P.M. There's nothing they can do except study and study. They have almost never got holiday. Even, they have to spend their summer vacations with studying preparing the exams.

Although finally Park Jae-in and Park Jae-kwon decided not to study at private academy anymore, both of them still study hard at home and keep showing their good achievement in school. Their decision not to study at private academy and not to take the university's entrance exam was taken because they have had other plans. Her ability in drawing makes Park Jae-in wants to be a great animator and his interest in performing art makes Park Jae-kwon dreams to be an excellent artist in the future. Therefore, they chose not to take the suneung exam and also decided not to go to private academy anymore. They don't want to go with the flow as friends and other people do that is going to university in order to be able to get a prestigious job in the future. Jae-in and Jae-kwon wants to be themselves. Doing something they want to.

Jae-in thinks that after completing her senior high school, the most appropriate further education for her is learning about animation in Animation Department, Korea National University of Art. And for Jae-kwon learning performing art at C.A.S.T Acting Academy in Apgujeong is the best for him. They are sure that both institutions can help them to realize their dreams. It is also said that Jae-kwon also gently refused his father advice to study performing art at one of the top ten universities, which has theater department. He refused it because before making decision he had collected sufficient information about the field of art performing by searching in various media and discussing with many people who has work in this field. And according to the information he got, he thinks that C.A.S.T is the most appropriate place for him to study. Jae-kwon firmly wants to get into that institution and prepared it well. And finally his effort is fruitful well. He got announcement that he got full scholarship from C.A.S.T.

“Аppa, I’m sorry. I want to study at C.A.S.T. (...) Appa, I want to make you proud of me, with my own dream. So, about suneung exam, I won't take it (Orizuka \& Indriana, 2013: 88). 
"Harabeoji have told your sister to study for suneung test. But she said she has had another plan, she wants to study animation at KNUA" (Orizuka \& Indriana, 2013: 162).

In O\&I, it seems that Jae-in and Jae-kwon represent teenagers who know their rights in the field of education that is as mentioned in Universal Declaration of Human Right article 26 that "Education shall be directed to the full development of the human personality and to the strengthening of respect for human rights and fundamental freedoms"3. Therefore as teenagers who have been able to find out their interests and talent and as figures who have been able to determine what kind of job they want to do in the future, they realize that they have right to get education according to their interest and talent. And they know well that they do not have obligation taking 'suneung' exams as almost other Korean teenagers do. Moreover, they also know that they should prepare their future's careers by themselves as early as possible for their brighter future. Their awareness of their rights also makes them do not feel burdened with good reputation of their father who graduated from Korea University and their grandfather who was Korea University's lecturer. Otherwise, the success of their father and grandfather encourage them to be successful although in a different way as quoted above.

Another interesting attitudes and decisions related to education are also shown by Choi Seung-won and Hye-rin. When many people think that formal education in schools is an obligation and great score, high rank in academic, high formal education in prestigious universities are considered as a key to get success in the future then they have another thought. In O\&I, it was narrated that Seung-won who has already started his career as a movie star and a model, who has received recognition from public as a talented star decided to quit his study in senior high school and will be more concentrated on his career in the field of entertainment. Even though his parents opposed his decision at first, but finally they realized that his son's decision is the best way for him and then they turned to support what he decided.

Meanwhile, since after graduating from high school she will be directly working in her family's company, Hye-rin also decided not to take suneung exam. Hye-rin thinks that she does not need

\footnotetext{
${ }^{3}$ http://www.un.org/en/universal-declaration-human-rights/
} 
to go to university. All she needs is practical work directly in his family's company. For Seung-won and Hye-rin break from senior high school and do not go to university is not a failure or evidence of their incompetence. On the contrary, these decisions are taken because both of them are willing to be more focus on their future plan. For them knowledge is not only be able to be accessed from formal education but practical work is also an important process of learning.

Based on the explanation above, it is implied that the parents in these fictions give freedom to their children to determine their own future. In the atmosphere like this, as a teenager, the figures in these teenlits are able to take advantage of the freedom given to them to explore their talents and interests. However, although their parents give them freedom, it does not cause them to lose their respect and appreciation to them. It's been said that they always convey their thoughts to their parents first before taking a decision. And as a democratic-minded parent who has awareness about children rights in education and personal life, their parents choose to support any decision that their children take.

Characters in SS and O\&I also depicted as figures who are aware that having many experience will also be useful for their future. Therefore, in order to gain a lot of experience, Jae-in, Jae-kwon, and Han Soon-hee use the time they have by doing internship program or part time job in the field related with their interest. Jae-in is doing internship as assistant animator in RGY Animation, a production house owned by Yoon Gi-joon, a famous film director. Jae-kwon does part time job as a movie dubber and makes cameo appearances in some dramas and advertisements. And Han Soon-hee is working at famous boutique as an assistant designer. They do those jobs not for economic purposes, but in order to seek knowledge and gain experience as much as possible.

"If she does not come it will get messed up. Only she can do this for me (...)" (Tan, 2006)

"Good job Jae-in. I will involve you in the next project ...” (Orizuka \& Indriana, 2013)

Though they are still very young, their abilities in the fields they want to do in the future have been recognized from the people around him as the designer talked about Han Soon-hee and Yoon director said about Jae-in above. From the attitudes and behaviors 
described above, it can be said that based on the stage in developmental psychology, the adolescents who appear in SS and O\&I can be categorized as teenagers who have been oriented toward the future and has earned self-objectification and self-insight.

Then, it has been mentioned before that literary work is a reflection of the author's mind. Therefore, it is quite possible if SS and O\&I are actually the author's attitude toward education in Korea. Moreover, since Lia Indra Andriana, one of the authors had ever lived in Korea for studying, so it is very possible that she has sufficient knowledge about social life in Korea. Through these fictions the authors actually are criticizing Korean education phenomenon that often makes students unhappy and lost their personal identity. They implicitly reminds all of us that if an education is only aimed at employability, if education for children is only intended to match them with jobs that already exist, then it is a violation of human rights. Education should be as stated by the father of education Paulo Freire that the purpose of education is to improve and enhance the lives of its own, determined by the concerned then parents should not intervene excessively. School or other educational institutions must be an artificial environment that is purposely created to develop children toward specific goals, especially to provide the ability and skill as a provision for later life. Thus, school must be a place for his student actualization. And hence, student, in this case teenager not only will be happy and challenged while studying there but student is also able to develop optimally his own, find his status or social identity, maximize and able to serve the community.

The authors also remind us that formal education is not the only way to bring our dream into reality, is not the only one method to be success. Knowledge can be obtained from anywhere. The authors also try to dismantle dominant discourse developed in the community that teens who have good performance are teenagers who have good academic achievement. They remind us that achievement is not only assessed from academic or formal education side, but talent, career, and experience is also a plus point for teenagers.

The criticism of the authors against the condition of education that less humane, education that less considers the needs of adolescents realized by the courage of the characters making their own decisions which related to their education. In short, as a teenager, characters in SS and O\&I are constructed as a figure who has already 
had intellectual independence that is able to formulate their plans and goals for the future, able to decide what kind of career they will be doing in the future, and able to find ways to realize them. It can be said that the decisions they made they use to wreak their desire to experiment, explore and develop their interests and talents as a process, which is very useful in constructing their self-identity.

\section{Conclusion}

Seen from the perspective of adolescence developmental psychology, through Summer in Seoul and Oppa \& I: Love Signs, Indonesian authors tried to construct Korean teenagers as figures who already have mature personality, with various intellectual independences. Their intellectual independences characterized by their ability to have a real principle on a matter and not to be easily swayed by circumstances. The ability to make their own decisions firmly and freely based on evidence, logical reasons, and advice from others, the ability to take responsibility for the risks of the decision, and also the ability to develop the potential and intellectual skills for living in a society and for the future. Then their ability not to bother other people, able to make friends with others, and their adaptability show that Korean teenagers have not only emotional independence, but also moral and social independence.

Based on the role they carried, it can be concluded that as a family member, as a son, daughter, brother, and sister, Korean teenagers represented as a figure who does not only take responsible for himself but also for others. Then seen from their relation with peers, Korean teenagers represented as figures that have already been able to expand his social relationships and also has been able to maintain those relationships. Furthermore, within the world of education, Korean teens described as figures that have been able to draw up a clear plan for the future.

Despite the fact that market became the trigger of the emergence of teenlits related to Korea in Indonesia, as a teenager literature, SS and O\&I does not only have a recreational function, as an entertainment for the reader, but also have educative function, give knowledge about life in Korea and also educate other young people through the ideology inserted by the authors about how 
a teenager should do and should be. This research is a preliminary study about Indonesian teenage literature related to Korea, a first step to conduct further research.

\section{References}

Davidson, Peter, Meyersohn, Rolf and Shils, Edward. 1986. Literary Taste, Culture and Mass Communication. Vol. 6: The Sociology of Literature. Great Britain: Cambridge University Press.

http://koreabizwire.com/korean-children-and-adolescents-rank-last-inoecd-happiness-index/53907

http://www.bbc.com/news/education-25187993

http://www.koreaherald.com/view.php?ud=20110504000759

http://www.un.org/en/universal-declaration-human-rights/

Kauma, Fuad. 1999. Teen sensation in Puberty. Jakarta: Kalam Mulia.

Lee Sun-Yi (이선이). 2007. Korea Today. 외국인을 위한 한국 현대 문화, 서울: 한국문화사.

Orizuka, Andriana and Lia, Indra. 2013. Oppa \& I: Love Signs. Jakarta: Haru.

Santrock, John W. 2003. Adolescene ( ${ }^{\text {th }}$ edition). New York: McGraw-Hill.

Sarwono, Sarlito Wirasan. 2007. Adolescent Psychology. Jakarta: PT. Raga Grafindo Persada.

Swingewood, Alan and Laurenson, Diana. 1972. The Sociology of Literature. Paladin.

Tan, Ilana. 2006. Summer in Seoul. Jakarta: Gramedia.

Widyaningrum, Yuliawati. 2014. The Phenomenon of Korean Wave in Indonesia At A Glance (unpublished). 